\title{
READINESS OF ISLAMIC HUMAN RESOURCES IN SUPPORTING THE DEVELOPMENT OF HALAL TOURISM IN WEST JAVA (EVIDENCE FROM THE HOSPITALITY INDUSTRY)
}

\author{
Joeliaty, Siti Noni Evita, Wa Ode Zunita \\ Universitas Padjadjaran Bandung Jawa Barat, Indonesia \\ Email : joeliaty@yahoo.co.id, sitinonievita@yahoo.com, waodezusnita@unpad.ac.id
}

\begin{abstract}
Introduction : The development of halal tourism experienced the largest growth compared to other types of tourism until 2018 in Indonesia. These developments lead to an increasingly higher level of human resources with skills and competencies in the field of sharia-compliant tourism services.

Objective : This research will explain the readiness of Islamic human resources to deal with such changes. The study examined the issue of Islamic HUMAN RESOURCES in Sharia Hotels with a sample of 200 employees as respondents.

Method : This research uses a qualitative approach, namely rasch model and SWOT analysis so that measurements with likert scale are more precise. Since the study's problems have never been studied before and there are not enough variables and constructions available, the authors use an exploratory approach.

Results : The results of this study show that the readiness of Shariah human resources in Sharia Hotels as measured by various competencies shows mixed results. Intellectual competence and competence in sharia science are found from low categories. In addition, anxiety levels and fatigue levels are high.

Conclusion : The readiness of human resources in Shariah hotels shows mixed results. The opportunity for islamic human resources management lies in the implementation of halal tourism standardization, both national and international standards. However, hospitality also faces a threat, namely an increase in the number of competitors. Therefore, the national halal hotel hospitality industry requires adequate education and training in Islamic human resources, both by relevant government agencies and other stakeholders. This effort is to support the increase of national halal tourism, especially in sharia hotel areas in West Java.
\end{abstract}

Keywords : Islamic HR, Competence, SWOT, Halal Tourism.

\section{Introduction}

Responding to the new challenges in facing global changes, the central government of Indonesia has set a target of 20 million foreign tourist visits in 2019. To achieve these targets, the government's efforts that need to be initiated are the involvement of other stakeholder regions and pillars (Chookaew et al., 2015). The tourism sector has proven to have made a contribution as a safety valve when the crisis occurred and at the same time provided a considerable multiplier effect on the growth of other sectors. Even this development can revive many small businesses and the informal sector related to tourism activities, including hawkers, stalls, tour guide services, and so on (Megawandi, 2013) 
In Law No. 10/ 2009 concerning Tourism, it is stated that Tourism is a travel activity carried out by a person or group of people through visits to certain places for recreational purposes, personal development, or to study the uniqueness of tourist attractions visited in the interim period (article 1 number 1). Travelers, according to the law, are people who do tourism (article 1 point 2). Along with the trend of halal tourism which is part of the global Islamic economy industry (Samori et al., 2016). Indonesia as one of the countries with a majority of Muslim population can be a pioneer in developing halal tourism in the world. The development of halal tourism can be an alternative for the tourism industry in Indonesia. Indonesia has the prospective to develop a superlative tourism industry, gaining from its prosperous tourism capabilities and a decisive tourism demand stance. Referring to the Global Muslim Travel Index (2018), Indonesia's rank has gone 4 levels to 2nd place, behind Malaysia, in the last 3 years.

West Java Province plays an important role in the process of achieving national development targets. The strategic position of West Java that supports the capital, the contribution of a population of $20 \%$ to the total national population, and various other identities confirm this important role. In the last few years, West Java has become a prima donna of national tourism with the Province of Bali and DIY Yogyakarta due to various uniqueness, natural beauty, and industrial creativity. The 2014 BPS data shows West Java is the second area after Bali which is the most visited by foreign tourists. Even so, the West Java tourism sector has not provided adequate contributions because the contribution is far from the national target. The tourism sub-sector in West Java has not been fully explored optimally (Abrori, 2021). This is reflected in the fluctuating growth in the number of tourists visiting West Java.

One type of tourism that is reliable and has enormous potential on the economic side in West Java is halal tourism (Perbawasari et al., 2019). Halal tourism is a tourism activity aimed at Muslim tourists. Halal tourism experienced the largest growth compared to other types of tourism until 2015. This development led to an increase in the need for skilled and competent human resources in the field of tourist services that refers to Sharia standards. One form of tourist service is sharia hotel services, which are characterized by the separation of male and female access to swimming pools and spa facilities and do not provide alcoholic beverages (Henderson, 2010). To support the development of halal tourism, especially the sharia hotel industry in West Java, human resources are required to have expertise in managing sharia hotels. Therefore, the preparation of Islamic human resources must be the main focus in the development of halal tourism, especially for sharia hotels in West Java. The purpose of this study is to produce a map of the condition of Islamic HR readiness in supporting halal tourism, especially the sharia hotel industry in West Java. 
Readiness of islamic human resources in supporting the development of halal tourism in west jawa (evidence from hospitality industry

\section{Research Methods}

a. Data Collection Techniques and Data Sources

Qualitative data collected using in-depth interview techniques with the hotel include (owner/directors, HRD, and employees) and processing data using Nvivo software (Rahardjo, 2011). Quantitative data collected is taken from the same party with qualitative data which includes (owner/directors, HRD, and employees) with questionnaire likert (Sugiyono, 2017).

a. Sampling

Sampling was carried out in several cities in West Java by data obtained from the Indonesian Ulema Council (MUI) of West Java Province. There are 16 sharia hotels in West Java that are all surveyed, including 5 hotels in Bandung City, 1 hotel in Tasikmalaya City, 3 hotels in Bekasi City, 2 hotels in Bogor City, 1 hotel in Sukabumi, 3 sharia hotels in Cirebon City, and 1 hotel in the city of Majalengka.

b. Data Validity

In testing the validity and reliability of qualitative research data, a credibility test, transferability test, dependability test, and confirmability test were carried out. Quantitative data uses the RASCH validity test model also with Winstep 3.73 software. An analysis of the value of Mean Square Outfit (MNSQ), X-Standard Outfit (ZSTD), and Point Measure Correlation (Pt Mean Corr) was carried out. Accepted Mean Square (MNSQ) Outfit value: $0.5<$ MNSQ < 1.5. The X-Standard Outfit (ZSTD) value accepted: $-2.0<$ ZSTD $<+2.0$. Value Point Measure Correlation (Pt Mean Corr) accepted: $0.4<$ Pt Mean Corr $<0.85$.

c. Data Analysis

In Quantitative analysis, thematic analysis is used, namely by identifying themes that are patterned in a phenomenon. Difficulty degree analysis is used to measure questions that become indicators of knowledge of HR in sharia aspects in the sharia hotel industry. Questions can be classified into easy, medium, difficult categories. It is difficult to understand that the indicators for these indicators have not been understood as sharia principles in the operationalization of sharia hotels. And the qualitative analysis used is the SWOT analysis.

\section{Research Results}

The respondents examined in this study were sharia hotel employees in West Java in Bandung City / Regency, Cirebon, Bogor, Bekasi, Cianjur, Sumedang, Majalengka, and Sukabumi. The following are descriptions of respondents based on gender, age, level of education, and work experience.

The number of male respondents is 127 people or $64 \%$, while the number of female respondents is 73 people or $37 \%$. In terms of age of respondents in the age range of 20-24 years, there were 54 people or $27 \%$, the second-highest position in the age range of 25-29 years amounted to 43 people or $22 \%$, the third-highest position in the age range 30-34 years amounted to 30 people or $15 \%$. This indicates that the majority 
of sharia hotel staff in West Java are generally very productive ages. While from the education level, the majority of respondents have a high school / high school background, totaling 126 people or $63 \%$. The second majority is at the 1-D3 / Academic Diploma level of 44 people or $22 \%$. The third-highest number of respondents is Bachelor (S1) / D4. Based on work experience, respondents with experience of 2-3 years totaled 52 people or $26 \%$. Furthermore, respondents experienced 4-5 years and 6 - 10 years totaling 48 people or $24 \%$ respectively. This indicates that the majority of sharia hotel employees in West Java already have sufficient work experience. This can be the basis for providing the best service for Sharia Hotel customers.

1. Validity and Reliability Test

In this study, the validity and reliability of the questionnaire were tested using Winstep 3.73 software, the output results are in Table 1.

Table 1

Data Input

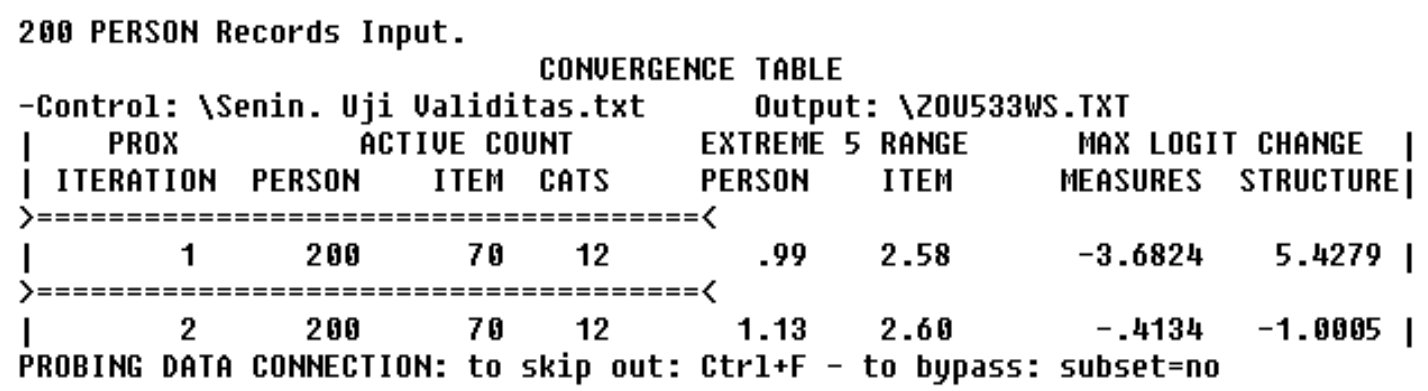

Source: Olah Data Winstep 3.73, 2018

Table 1 shows data from 200 respondents on the 70 question items. We elaborated on the various competencies of the observed sharia hotel employees. We then conducted the validity and reliability test of each dimension using Winstep 3.73. The results can be seen in Table 2. Competency variables consist of Intellectual competency, emotional competency, social competency, and sharia competence. In addition, the results of measurement of anxiety and burnout inventory are expressed in the modified Zung SelfRating Anxiety Scale, and Copenhagen Burnout Inventory, as shown in Table 2.

Table 2

Summary of Validity and reliability test results

\begin{tabular}{|c|c|c|c|}
\hline Data & $\begin{array}{c}\text { Statistical } \\
\text { test }\end{array}$ & $\begin{array}{c}\text { Statistic } \\
\text { Value }\end{array}$ & Criterion \\
\hline \multirow{2}{*}{ Intellectual Competency } & $\begin{array}{l}\text { Test of } \\
\text { Validity }\end{array}$ & $\begin{array}{l}\text { MNSQ = } \\
0,99 \\
\text { ZSTD = - } \\
0,2\end{array}$ & Valid \\
\hline & $\begin{array}{l}\text { Test of } \\
\text { Realibility }\end{array}$ & $\begin{array}{l}\text { Cronbach } \alpha= \\
0,5 \\
\text { Reliability }= \\
0,99\end{array}$ & $\begin{array}{l}\text { Inconsistent } \\
\text { Highly } \\
\text { reliable }\end{array}$ \\
\hline
\end{tabular}


Readiness of islamic human resources in supporting the development of halal tourism in west jawa (evidence from hospitality industry

\begin{tabular}{|c|c|c|c|}
\hline Data & $\begin{array}{c}\text { Statistical } \\
\text { test }\end{array}$ & $\begin{array}{l}\text { Statistic } \\
\text { Value }\end{array}$ & Criterion \\
\hline \multirow[b]{2}{*}{ Emotional Competency } & $\begin{array}{l}\text { Test of } \\
\text { Validity }\end{array}$ & $\begin{array}{l}\text { MNSQ = } \\
1,03 \\
\text { ZSTD = } 1\end{array}$ & Valid \\
\hline & $\begin{array}{l}\text { Test of } \\
\text { Realibility }\end{array}$ & $\begin{array}{l}\text { Cronbach } \alpha= \\
0,83 \\
\text { Reliability }= \\
0,98\end{array}$ & $\begin{array}{l}\text { Consistent } \\
\text { Highly } \\
\text { reliable }\end{array}$ \\
\hline \multirow[b]{2}{*}{ Social Competence } & $\begin{array}{l}\text { Test of } \\
\text { Validity }\end{array}$ & $\begin{array}{l}\text { MNSQ = } \\
0,94 \\
\text { ZSTD }=1,9\end{array}$ & Valid \\
\hline & $\begin{array}{l}\text { Test of } \\
\text { Realibility }\end{array}$ & $\begin{array}{l}\text { Cronbach } \alpha= \\
0,84 \\
\text { Reliability }= \\
0,96\end{array}$ & $\begin{array}{l}\text { Consistent } \\
\text { Highly } \\
\text { reliable }\end{array}$ \\
\hline \multirow{2}{*}{ Sharia Competency } & $\begin{array}{l}\text { Test of } \\
\text { Validity }\end{array}$ & $\begin{array}{l}\text { MNSQ = } \\
1,07 \\
\text { ZSTD = - } \\
0,2\end{array}$ & Valid \\
\hline & $\begin{array}{l}\text { Test of } \\
\text { Realibility }\end{array}$ & $\begin{array}{l}\text { Cronbach } \alpha= \\
0,84 \\
\text { Reliability }= \\
0,98\end{array}$ & $\begin{array}{l}\text { Consistent } \\
\text { Highly } \\
\text { reliable }\end{array}$ \\
\hline \multirow[b]{2}{*}{ Zung Anxiety Level } & $\begin{array}{l}\text { Test of } \\
\text { Validity }\end{array}$ & $\begin{array}{l}\text { MNSQ }= \\
1,12 \\
\text { ZSTD }=0,5\end{array}$ & Valid \\
\hline & $\begin{array}{l}\text { Test of } \\
\text { Realibility }\end{array}$ & $\begin{array}{l}\text { Cronbach } \alpha= \\
0,84 \\
\text { Reliability }= \\
0,89\end{array}$ & $\begin{array}{l}\text { Consistent } \\
\text { Good }\end{array}$ \\
\hline \multirow{2}{*}{$\begin{array}{l}\text { Copenhagen Burnout } \\
\text { Inventory }\end{array}$} & $\begin{array}{l}\text { Test of } \\
\text { Validity }\end{array}$ & $\begin{array}{l}\text { MNSQ = } \\
1,06 \\
\text { ZSTD }=0,3\end{array}$ & Valid \\
\hline & $\begin{array}{l}\text { Test of } \\
\text { Realibility }\end{array}$ & $\begin{array}{l}\text { Cronbach } \alpha= \\
0,84 \\
\text { Reliability }= \\
0,96\end{array}$ & $\begin{array}{l}\text { Consistent } \\
\text { Highly } \\
\text { reliable }\end{array}$ \\
\hline
\end{tabular}

Based on Table 2 shows that the question of intellectual competence meets two criteria then the item statement can be used, valid and reliable. Similarly, other questions regarding the readiness of Islamic human resources, including emotional competence, social competence, the competence of sharia, level of anxiety, and burnout inventory are valid and reliable. In Table 2, the reliability output of the question items on intellectual competence has a reliable value, based on the test results with the Rasch model. The reliability value is 0.99 . According to (Sumintono \& Widhiarso, 2014) these results are special. But based on the Cronbach alpha test results, the value of $\mathrm{r} 11=0.50$, which indicates that the items of intellectual competence questions in this study will give different results if tested back to employees. 
Whereas, the results of the Cronbach alpha test on dimensions are as follows: emotional competence $=0.83$; social competence $=0.84$; competency $=0.84$; and the level of anxiety and burnout inventory is 0.84 . This shows that the questions in this dimension will produce almost the same results if tested back to employees. The reliability test results using the Rasch model in Table 2 show that the dimensions of emotional, social, sharia, and Burnout Inventory competencies are special. Test results on the dimensions of the anxiety scale are good

2. Descriptive Analysis

Table 3

Summary of Descriptive Analysis of Sharia Hotels in West Java

\begin{tabular}{lrl}
\hline \multicolumn{1}{c}{ Data } & $\begin{array}{c}\text { Cumulative } \\
\text { Score }\end{array}$ & \multicolumn{1}{c}{ Criteria } \\
\hline Intellectual Competency & 1.879 & Low \\
Emotional Competency & 5.779 & High \\
Social Competency & 4.067 & High \\
Shariah Competency & 3.964 & Low \\
Anxiety Level Zung Method & 13.614 & Very high \\
Burnout Frequency & 8.923 & Very high \\
BurnoutDegree Level & 2.820 & Low \\
\hline
\end{tabular}

Source: processed primary data, 2018

a. Intelectuintellectually

Table 3 shows that the intellectual competency of sharia hotel employees is at a low interval, which means that having competence in work is not by applicable professional standards (Purwanto \& Taufik, 2013). This needs special attention from stakeholders such as hotel management, university government, and the public to increase the intellectual competency of employees in the Java Sharia Hotels, stakeholders must conduct training, development, certification, and other facilities for hotel sharia employees because humans are strategic assets to achieve the organization's vision and mission.

b. Emotional competency

The emotional competency of Sharia Hotel employees in West Java is at high intervals. In this case, it means that employees are good, communicative, friendly, honest, and responsible. This competency can be a resource to provide service excellence to customers. Emotional competency can still e increased at very high intervals, considering that hotels are service industries. One of the most important elements is that the waiter can satisfy customers and other stakeholders (Siti Maryam, 2017).

c. Social competency

Social competency is an inherent part of each individual, stating that Sharia Hotel employees in West Java are at high intervals (Table 3). This means that employees are polite and attracted to Islamic values and ethics. Competence is good but needs to be increased again to be at a very high interval. This is done through growing a sense of responsibility to others and the environment by continuing to 
Readiness of islamic human resources in supporting the development of halal tourism in west jawa (evidence from hospitality industry

promote social programs, CSR, and others that benefit the surrounding community (Narissa, 2019).

d. Sharia competency

The uniqueness of sharia hotels should be supported by competent employees (Narissa, 2019). But the fact is that the employees' sharia competency is still at a low interval (Table 3), which means that employees do not understand and can implement Islamic values in carrying out their duties. This Competency needs more attention, through investing in quality human resources that support the uniqueness of sharia hotels. The investment can be in the form of providing courses on sharia hotels. The government may provide clear rules about sharia competency assisted by academics who are interested in this field.

e. Modified Zung Self_Rating Anxiety Scale

In Table 3 it can be seen that the modified Zung anxiety interval self_rating anxiety scale is very high. This indicates that employees in sharia hotels in West Java need to pay attention to maintaining the best talents to work optimally by applying merit systems where the implementation of reward and punishment is applied fairly by observing the Equal Employee Opportunity principle.

f. Copenhagen Burnout Inventory

Frequency degree burnout intervals are located at very high intervals (Table 3). This indicates that the work experienced by sharia hotel employees in West Java has a large workload that often feels exhausted. The management should think about efforts to divide the work evenly to reduce the frequency of fatigue (Sudaryo et al., 2018). In addition, burnout degree levels are at low intervals (Table 3). This is because the work is more physical than emotional. This is because in general, the employees in the Syariah hotel in West Java use physical work more.

g. Characteristic of Prophet Muhammad Sallallahu Alaihi Wassallam

This question measures the understanding of the nature of the Prophet Muhammad Sallallahu Alaihi Wassallam which can be an example of behaving and behaving thoroughly in applying Islamic principles. After researchers recapitulated 4 questions about the nature of the Prophet, each question was worth 25 points, in 200 respondents when averaged the value was 65.25 on a scale of 100 . This indicates that there are still many sharia hotel employees in West Java who do not yet know the nature of the Prophet. Sharia hotel management is expected to facilitate employees to actively participate in religious studies to increase competence. In addition, it can also increase the faith and devotion that affects performance (Zarmis et al., 2020).

h. SWOT Analysis

SWOT analysis is used to discuss internal factors and external factors of Islamic human readiness in supporting the development of halal tourism in West Java (Sari, 2021). The SWOT analysis clearly illustrates how the opportunities and threats faced can be adjusted to the strengths and weaknesses possessed in the readiness of Islamic human resources in supporting the development of halal tourism in West Java. First, internal factors, AMDAL licensing process consists of strengths 
and weaknesses. Picture 1 shows the results of IFAS (Internal Factor Analysis Summary) and EFAS (External Factor Analysis Summary).

\begin{tabular}{|c|c|c|}
\hline \multirow{13}{*}{ 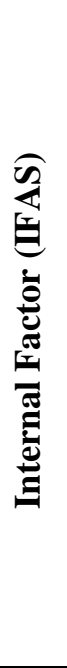 } & Stre & Weakness (W) \\
\hline & $\mathrm{S} 1$ employees are generally at productive age & W1 Low level of intellectual competence \\
\hline & S2 Multitasking ability & W2 does not have a professional stand \\
\hline & S3 High Loyalty & W3 The absence of a formal association \\
\hline & S4 The concept of smile, greeting, courtesy, & that covers sharia hotels W4 many \\
\hline & $\begin{array}{l}\text { courtesy, and quick response } \\
\text { S5 Information on prayer times }\end{array}$ & $\begin{array}{l}\text { employees come from conventional } \\
\text { hotels }\end{array}$ \\
\hline & S6 Stop working in the time of prayer & W5 Level of competence in sharia is low \\
\hline & $\begin{array}{l}\text { S7 Services by sharia, for example, food is } \\
\text { guaranteed halal }\end{array}$ & $\begin{array}{l}\text { W6 There is less regular training and } \\
\text { development }\end{array}$ \\
\hline & S8 Every employee can read the Qur'an & W7 Average high school education \\
\hline & S9 Able to understand sharia concepts & W8 Salary is paid at the provincial \\
\hline & S10 all activities are adjusted to sharia s & government standard \\
\hline & $\begin{array}{l}\text { S11 Always greet you in welcoming } \\
\text { S12 Female staff wearing veils }\end{array}$ & $\begin{array}{l}\text { W9 Lack of skills in the use of } \\
\text { technology }\end{array}$ \\
\hline & S13 Has a high level o & W10 Knowledge of Islam is not optimal \\
\hline \multirow{6}{*}{ 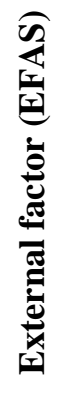 } & $\begin{array}{r}\text { Oppo } \\
\text { O1 PHRI Syariah / The }\end{array}$ & Threat $(\mathbf{T})$ \\
\hline & O2 Stan & T1 Lot \\
\hline & O3 Increased tourists staying overnight & T2 Not responsive in the monitoring of \\
\hline & O5 More Media that can inform sharia hotels & T3 Work productivity level \\
\hline & O6 Establishment of Sharia Universities & T4 Decreased loyalty level \\
\hline & O7 Government gives attention to sharia hotels & $\begin{array}{l}\text { T5 Increasing technological } \\
\text { developments }\end{array}$ \\
\hline
\end{tabular}

\section{Conclusion}

The following are some conclusion points based on the results of the study: 1 . Islamic HR Readiness The Sharia Hotel Industry in West Java can be mapped through a variety of related HR competencies, among them intellectual competence at a low, emotional and social competence at a high level, but competence on the concept of sharia at a low level and anxiety and burnout at a high level. 2. Internal factors relating to the greatest strength of Islamic hotel Islamic HR include; HR in productive age, multitasking ability, services by Shari'a, all activities are adjusted to sharia patterns and can understand sharia especially tourism in Islamic law. 3. Internal factors related to the greatest weaknesses of Islamic human resources in sharia hotels include the low level of intellectual competence, lack of standardization, low level of competence of sharia, and lack of training and periodic development 4. External factors relating to the greatest opportunities for Islamic HR in sharia hotels include opportunities for standardization, the establishment of PHRI Syariah / or sharia hotel associations, and an increase in the number of guest houses. 5. External factors related to the greatest threat of Islamic human resources in sharia hotels include a lot of competition, weak supervision of the marital status of guests checking in pairs, levels of work productivity, and decreased levels of loyalty. 
Readiness of islamic human resources in supporting the development of halal tourism in west jawa (evidence from hospitality industry

\section{DAFTAR PUSTAKA}

Abrori, F. (2021). Pariwisata Halal Dan Peningkatan Kesejahteraan. Literasi Nusantara.

Chookaew, S., Chanin, O., Charatarawat, J., Sriprasert, P., \& Nimpaya, S. (2015). Increasing halal tourism potential at Andaman Gulf in Thailand for Muslim country. Journal of Economics, Business and Management, 3(7), 739-741.

Henderson, J. C. (2010). Sharia-compliant hotels. Tourism and Hospitality Research, 10(3), 246-254.

Megawandi, Y. (2013). Koordinasi Antar Organisasi Dalam Pembangunan Pariwisata Di Provinsi Kepulauan Bangka Belitung.

Narissa, A. (2019). Faktor-Faktor yang Mempengaruhi Employee Engagement pada Hotel Lembah Sarimas. STIE Indonesia Banking School.

Perbawasari, S., Sjuchro, D. W., Setianti, Y., Nugraha, A. R., \& Muda, I. (2019). Halal tourism communication formation model in west Java, Indonesia. Geo Journal of Tourism and Geosites, 25(2), 309-320.

Purwanto, S., \& Taufik, S. (2013). Hubungan antara pola asuh demokratis dengan kedisiplinan anak asuh di panti asuhan yatim muhammadiyah ning amriyah soepardho Kendal. Universitas Muhammadiyah Surakarta.

Rahardjo, M. (2011). Metode pengumpulan data penelitian kualitatif.

Samori, Z., Salleh, N. Z. M., \& Khalid, M. M. (2016). Current trends on Halal tourism: Cases on selected Asian countries. Tourism Management Perspectives, 19, 131136.

Sari, D. A. P. (2021). Potensi wisata halal Pantai Natal Kabupaten Mandailing Natal. IAIN Padangsidimpuan.

Siti Maryam, N. (2017). Mewujudkan good governance melalui pelayanan publik. JIPSI-Jurnal Ilmu Politik Dan Komunikasi UNIKOM, 6.

Sudaryo, Y., Aribowo, A., \& Sofiati, N. A. (2018). Manajemen Sumber Daya Manusia: Kompensasi Tidak Langsung dan Lingkungan Kerja Fisik. Penerbit Andi.

Sugiyono. (2017). Metode Penelitian Kuantitatif, Kualitatif, dan R\&D. Alfabeta.

Sumintono, B., \& Widhiarso, W. (2014). Aplikasi model Rasch untuk penelitian ilmuilmu sosial (edisi revisi). Trim Komunikata Publishing House.

Zarmis, Z., Lahmi, A., \& Rasyid, A. (2020). Peran Musyawarah Guru Mata Pelajaran PAI dalam Meningkatkan Kompetensi Pendidik Sekolah Menengah Pertama di Kabupaten Padang Pariaman, Sumatera Barat, Indonesia. Arfannur, 1(1), 27-40. 